\title{
Renal Involvement in Chronic Lymphocytic Leukemia: A Case Report
}

\author{
Kronik Lenfositik Lösemi'de Böbrek Tutulumu: Olgu Sunumu
}

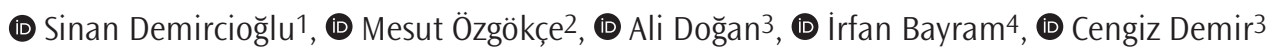

${ }^{1}$ Necmettin Erbakan University Meram Faculty of Medicine, Department of Hematology, Konya, Turkey

2Van Yüzüncü Yıl University Faculty of Medicine, Department of Radiology, Van, Turkey

${ }^{3}$ Van Yüzüncü Yıl University Faculty of Medicine, Department of Hematology, Van, Turkey

${ }^{4}$ Van Yüzüncü Yıl University Faculty of Medicine, Department of Pathology, Van, Turkey

\begin{abstract}
Chronic lymphocytic leukemia (CLL) is a neoplastic condition of B cells that frequently affects the lymph nodes, liver, spleen and bone marrow. The extranodal involvement of CLL is most commonly observed in the skin, whereas gastrointestinal and genitourinary involvement is rare. Renal involvement may not always present with renal failure. In this study, we aimed to present a patient with CLL infiltration in the kidney without renal failure and proteinuria.
\end{abstract}

Keywords: Chronic lymphocytic leukemia, extranodal, kidney, involvement

\section{$\ddot{0} Z$}

Kronik lenfositik lösemi (KLL) lenf bezlerini, karaciğer, dalak ve kemik iliğini sıkça etkileyen B hücrelerinin neoplastik bir durumudur. KLL'nin ekstranodal tutulumu en sık ciltte görülür. Gastrointestinal ve genitoüriner tutulum nadir izlenir. Böbrek tutulumu karşımıza her zaman böbrek yetmezliği ile gelmeyebilir. Bu çalıșmada böbrek yetmezliği ve proteinürisi olmayan hastada böbrekte KLL enfiltrasyonu saptadığımız bir olguyu sunmayı amaçladık.

Anahtar Kelimeler: Kronik lenfositik lösemi, ekstranodal, böbrek, tutulum

\section{Introduction}

Chronic lymphocytic leukaemia (CLL)/small lymphocytic lymphoma (SLL) is a mature B-cell neoplasm characterized by the progressive accumulation of monoclonal B lymphocytes. Malignant cells in CLL and SLL have the same pathological and immunophenotypic properties. CLL/ SLL accounts for approximately $25 \%-30 \%$ of all leukemias (1) and is more common in men than in women (male: female ratio is between 1.3:1 and 1.7:1) (1,2). It is considered to occur commonly in older adults, and the median age of incidence is 70 years (3). In most cases, diagnosis is made by the investigation of lymphocytosis identified during routine examination. Symptomatic cases may present with complaints related to lymphadenomegaly or organomegaly (splenomegaly or hepatomegaly) and/or general symptoms, such as fatigue, weight loss, anorexia and fever (4). CLL/SLL cells can infiltrate into any organ, but because of its ease of examination, the most frequently involved non-lymphoid tissue at the time of diagnosis is the skin. Skin lesions (leukemia cutis) on the face are most common and present as maculae, papules, plaques, nodules, ulcers or blisters (5). Unlike other lymphomas, clinically significant gastrointestinal mucosal involvement is rare in CLL/SLL. Similarly, meningeal leukemia is not expected at the time of diagnosis (6).

\section{Case Report}

A 63-year-old male patient was being followed up with a diagnosis of Stage 2 CLL since 2016. The patient complained of night sweats for several years. Physical examination revealed cervical, axillary and inguinal lymphadenopathies (LAP) that were painless, soft and mobile, with the largest being $2 \mathrm{~cm}$ in diameter. In addition, masses of $3-5 \mathrm{~cm}$ were palpated on the liver and spleen and under the ribs. Leukocyte count was 44.160/microL, Iymphocyte count was 32.870/ microL, hemoglobin level was $12.40 \mathrm{~g} / \mathrm{dL}$, platelet count was 272.120/ microL, creatinine was $1.14 \mathrm{mg} / \mathrm{dL}$ and lactate dehydrogenase was 189 $\mathrm{U} / \mathrm{L}$. Complete urinalysis did not reveal proteinuria. The results of bone marrow biopsy were suggestive of CLL. In the genetic examination, 90\% of the analyzed cells had a deletion in the $13 q 14.3$ region, and $11 q 22.3$, trisomy 12, 17p13.1 deletion and p53 mutation were not observed. Abdominal ultrasonography (USG) revealed hepatosplenomegaly, LAPS in the abdomen and a heterogeneous lesion ( $17 \mathrm{~mm}$ in diameter) in the
Address for Correspondence/Yazıșma Adresi: Sinan Demircioğlu MD, Necmettin Erbakan University Meram Faculty of Medicine, Department of Hematology, Konya, Turkey

Phone: +90 5554324474 E-mail: sinandemircioglumd@gmail.com ORCID ID: orcid.org/0000-0003-1277-5105

Cite this article as/Atıf: Demircioğlu S, Özgökçe M, Doğan A, Bayram İ, Demir C. Renal Involvement in Chronic Lymphocytic Leukemia: A Case Report. İstanbul Med J 2020; 21(2): 152-4.
Received/Geliș Tarihi: 10.10.2019 Accepted/Kabul Tarihi: 11.02 .2020

(C) Copyright 2020 by the University of Health Sciences Turkey, Istanbul Training and Research Hospital/istanbul Medical Journal published by Galenos Publishing House.

(C) Telif Hakkı 2020 Sağıı Bilimleri Üniversitesi Istanbul Ĕgitim ve Araştırma Hastanesi/Istanbul Tıp Dergisi, Galenos Yayınevi tarafından basılmıștır. 
left kidney upper pole. Abdominal computed tomography (CT) revealed a hypodense lesion of approximately $22 \times 18 \mathrm{~mm}$, with a mean density of 69 Hounsfield units in the left kidney upper pole posterior (Figure 1). Needle biopsy was performed on this lesion, and the following results were reported: CD20 (+), CD5 (+), CD23 (+), Bcl2 (+), CD3 (-), CD10 $(-)$, Bcl6 (-), cyclin D1 (-), TdT (-) and Ki67 proliferation index was $5 \%$. A diagnosis of CLL/SLL was made (Figure 2). The overall condition of the patient was good, with an Eastern Cooperative Oncology Group performance score of 1 . Thus, rituximab-bendamustine chemotherapy was started. Informed consent was obtained from the patient.

\section{Discussion}

Renal insufficiency is common in patients with CLL, with a prevalence of $7.5 \%$ at the time of diagnosis and $16.2 \%$ over the course of the disease (7). The mechanism of renal insufficiency in these patients is variable. CLL infiltration can cause compression on renal tubules and microvasculature, resulting in renal obstruction and ischemia. Other potential causes of renal insufficiency in patients with CLL include contrast-induced nephropathy, treatment-induced tumor

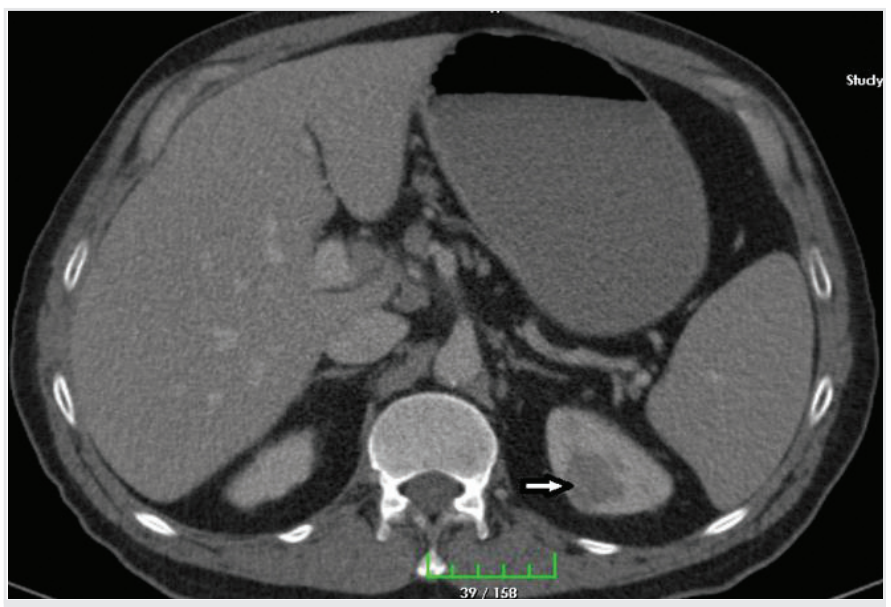

Figure 1. Focal hypodense area of hypodense localized in the upper pole of the left kidney (White arrow)

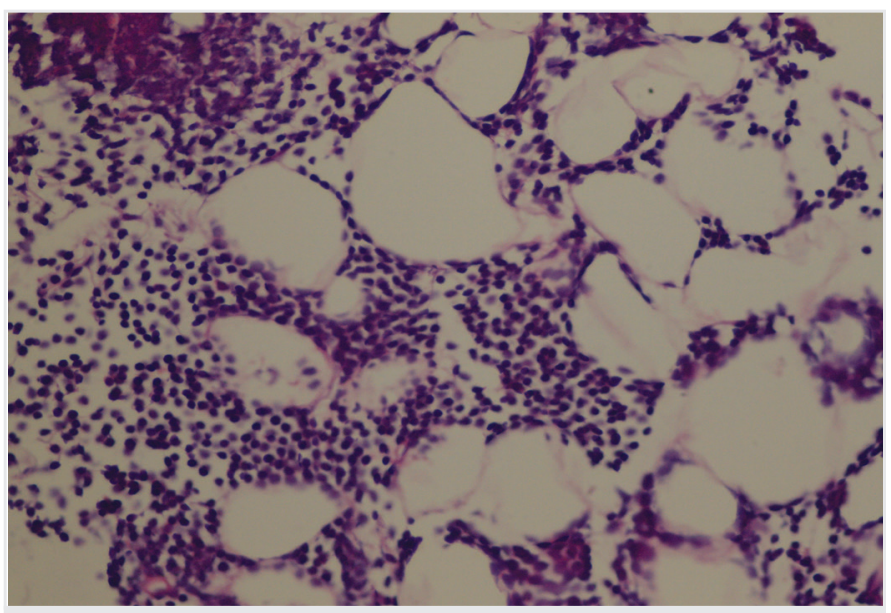

Figure 2. Chronic Iymphocytic leukaemia/small lymphocytic lymphoma infiltration in the renal hilar fatty tissue. Mature-looking lymphocytes that show infiltration between fat cells can be observed in the section (hematoxylin and eosin staining, x40 magnification)
Iysis, chemotherapy-induced toxicity and ureteral obstruction with lymphadenopathy (8). CLL can also result in various glomerular pathologies, including acute glomerulonephritis, nephrotic syndrome and chronic glomerulonephritis (8).

In a previous study, among the 4024 patients diagnosed with CLL and monoclonal B-cell lymphocytosis at Mayo Clinic, renal biopsy was performed in 49 patients (1.2\%) due to renal insufficiency and nephrotic syndrome. Biopsy results revealed membranoproliferative glomerulonephritis (20\%), CLL interstitial infiltration as primary etiology (12\%), thrombotic microangiopathy (12\%) and minimal change disease (10\%) (9). In another study, renal biopsy was performed in 15 patients diagnosed with CLL, and CLL infiltration was detected in 10 of these patients (10). In a study on 700 patients with non-Hodgkin's lymphoma and CLL, renal infiltration was detected only in five patients (11). The retrospective evaluation of 52 patients with malignant B-cell infiltration in the kidney revealed that patients were diagnosed with Waldenström's macroglobulinemia $(n=21), C L L(n=11)$, diffuse large B-cell lymphoma $(n=8)$, other lymphomas $(n=11)$ and multiple myeloma $(n=1)(12)$. Contrary to these data, autopsy studies have indicated that $60 \%-90 \%$ of the patients have leukemic cell infiltration in the kidneys, but renal function remains intact even in late stages (13).

Renal insufficiency at diagnosis was found to be associated with male sex, advanced age, more advanced disease and CD49d positivity. Acute kidney injury developed in $16 \%$ of the patients during follow-up. The development of renal insufficiency during follow-up was shown to be associated with advanced age, male sex and certain CLL characteristics (Immunoglobulin heavy chain variable region genes unmutated, $\mathrm{CD} 4 \mathrm{~d}^{+}, \mathrm{CD}^{+} 8^{+}, \mathrm{ZAP}^{-} 70^{+}$, del17p $\mathrm{p}^{-}$and del11 $\mathrm{q}^{-}$) (7). It has been reported that renal function improves with CLL treatment in several patients with infiltrative disease on biopsy (10).

In a study, the presence of renal disease was found to be independently associated with adverse patient outcomes in CLL. It was shown that overall survival is significantly lower in patients with renal disease at the time of CLL diagnosis or during follow-ups than in patients without renal disease (9).

The most common imaging finding of renal involvement in leukemia is nephromegaly, which can affect one or both kidneys and is caused by widespread or nodular parenchymal infiltration of leukemic cells (14). However, the sensitivity and specificity of this finding remain unknown. For example, nephromegaly was detected only in 1 of the 10 patients with proven renal infiltration on biopsy (10). Obstructive uropathy can also be observed in CLL. Diagnosis can be made using imaging methods, such as USG, CT and magnetic resonance imaging (15).

In conclusion, renal involvement is rarely observed in CLL. Each case of renal insufficiency observed in CLL may not be related to infiltration. Post-renal renal insufficiency due to paraneoplastic syndromes, tumor lysis syndrome, chemotherapy-related toxicity and lymphadenopathies should not be overlooked.

\section{Ethics}

Informed Consent: Informed consent was obtained from the patient. 
Peer-review: Externally peer-reviewed.

Authorship Contributions: Surgical and Medical Practices - S.D., M.Ö., A.D., C.D.; Concept - S.D., I.B., C.D.; Design - S.D., A.D., İ.B., C.D.; Data Collection or Processing - S.D., A.D., I.B., C.D.; Analysis or Interpretation S.D., M.Ö., İ.B.; Literature Search - S.D., M.Ö., C.D.; Writing - S.D.

Conflict of Interest: No conflict of interest was declared by the authors.

Financial Disclosure: The authors declared that this study received no financial support.

\section{Referanslar}

1. Siegel RL, Miller KD, Jemal A. Cancer statistics, 2019. CA Cancer J Clin 2019; 69: 7-34.

2. Hernandez JA, Land KJ, McKenna RW. Leukemias, myeloma, and other lymphoreticular neoplasms. Cancer 1995; 75(1 Suppl): 381-94.

3. Smith A, Howell D, Patmore R, Jack A, Roman E. Incidence of haematological malignancy by sub-type: a report from the Haematological Malignancy Research Network. Br J Cancer 2011; 105: 1684-92.

4. Soysal T. Kronik Lenfositik Lösemi-Küçük Lenfositik Lenfoma. Hematolog 2013; 3: 253-70

5. Agnew KL, Ruchlemer R, Catovsky D, Matutes E, Bunker CB. Cutaneous findings in chronic lymphocytic leukaemia. Br J Dermatol 2004; 150: 1129-35.

6. Strati P, Uhm JH, Kaufmann TJ, Nabhan C, Parikh SA, Hanson CA, et al. Prevalence and characteristics of central nervous system involvement by chronic lymphocytic leukemia. Haematologica 2016; 101: 458-65.
7. Strati P, Shanafelt TD. Monoclonal B-cell lymphocytosis and early-stage chronic lymphocytic leukemia: diagnosis, natural history, and risk stratification Blood 2015; 126: 454-62

8. Hricik DE, Chung-Park M, Sedor JR. Glomerulonephritis. N Engl J Med 1998; 339: 888-99.

9. Strati P, Nasr SH, Leung N, Hanson CA, Chaffee KG, Schwager SM, et al. Renal complications in chronic lymphocytic leukemia and monoclonal B-cell Iymphocytosis: the Mayo Clinic experience. Haematologica 2015; 100: 1180-8.

10. Poitou-Verkinder AL, Francois A, Drieux F, Lepretre S, Legallicier B, Moulin $B$, et al. The spectrum of kidney pathology in B-cell chronic lymphocytic leukemia / small lymphocytic lymphoma: a 25-year multicenter experience. PLoS One 2015; 10: e0119156.

11. Da'as N, Polliack A, Cohen Y, Amir G, Darmon D, Kleinman Y, et al. Kidney involvement and renal manifestations in non-Hodgkin's lymphoma and lymphocytic leukemia: a retrospective study in 700 patients. Eur J Haematol 2001; 67: 158-64

12. Javaugue V, Debiais-Delpech C, Nouvier M, Gand E, Chauvet S, Ecotiere L, et al. Clinicopathological spectrum of renal parenchymal involvement in B-cell lymphoproliferative disorders. Kidney Int 2019.

13. Barcos M, Lane W, Gomez GA, Han T, Freeman A, Preisler H, et al. An autopsy study of 1206 acute and chronic leukemias (1958 to 1982). Cancer 1987; 60: 827-37.

14. Bach AG, Behrmann C, Holzhausen HJ, Katzer M, Arnold D, Spielmann RP, et al. Prevalence and patterns of renal involvement in imaging of malignant lymphoproliferative diseases. Acta Radiol 2012; 53: 343-8.

15. Sheth S, Ali S, Fishman E. Imaging of renal lymphoma: patterns of disease with pathologic correlation. Radiographics 2006; 26: 1151-68. 